\title{
Evolution of a Strange Pathology: HRM as a Strategic Business Partner and Employee Advocate in the USA
}

\author{
Ernie Stark $^{1}$ (D) Paul Poppler ${ }^{2}$
}

Published online: 22 September 2016

(C) Springer Science+Business Media New York 2016

\section{Introduction}

A number of ways of thinking about the management of workers and employees in the U.S. preceded today's highly publicized concept of Strategic Human Resource Management. Beginning in the early 1900s, these methods were known variously as Employee Relations, Personnel Management, Labor Relations, and Industrial Relations (Kaufman and AldaoZapiola 2014). A common feature across all of these approaches was a sense of humanism, a serious rejection of the notion that employees are a commodity whose sole purpose is to produce more output and wealth for the employer. Rather, employees were viewed as human beings with rights to decent terms and conditions of employment, fair treatment, voice, and participation (Kaufman 2008).

Reflecting the work of Elton Mayo (1933), Chris Argyris (1957) Douglas McGregor (1960), Victor Vroom (1964), and others, these early approaches to managing employees gave rise to internal functions that largely embraced employee-centered roles and focused on creating and administering pay, training, and development systems that serviced the needs of an organization's workforce (Brown et al. 2009). In the 1970s, these various approaches came to coalesce under the overarching concept of Human Resource Management (HRM), an internal organizational function that supported the product or service value chain by ensuring that workers were provided channels of due process and employee voice necessary to enhance the efficiency and equity of the employment relationship (Kaufman 2001; Godard 2014). From those earlier approaches, HRM acceded to a long-standing expectation that the responsibility of any attempt to manage human resources or administer personnel policy required serving as an advocate for employee welfare (Van Buren et al. 2011).

Ernie Stark

eescad@rit.edu; estarkphd@me.com

1 Saunders College of Business, Rochester Institute of Technology, Global Village Building 400, Room 2075, 6000 Reynolds Drive \#5006, Rochester, NY 14623-5603, USA

2 College of Business, Bellevue University, 1000 Galvin Road South, Bellevue, NE 68005, USA 
As Bob Dylan astutely observed about the turbulent social changes of the 1960s, "The times they are a-changing," and perhaps that observation is an appropriate comment on the fundamental shifts now occurring in HRM theory and practice. A judicious review of contemporary definitions of the HRM function merges around statements such as, "Essentially, the purpose of HRM is to maximize the productivity of the organization by optimizing the effectiveness of its employees" (Sims and Sauser 2014, 2). An alternative example is, "Human resource management involves the management of human skills and talents to make sure they are used effectively and in alignment with an organization's strategic goals" (Morgan-Youssef and Stark 2014, 4). While human resource professionals might argue that a concern for employee welfare undoubtedly is always implicit, current characterizations of the HRM functions provide little indication of a priority for serving employees except from purely transactional pursuits wherein the HRM function increases its organizational legitimacy by adopting the current prevailing organizational ethos: efficiency and strategic alignment. A reasonable argument could be made that the modern-day HRM function now embraces an intense obligation to promote the interests of the employer whilst aiding the organization in discharging its minimal required legal (and perhaps to a lesser extent, ethical) obligation to employees (Van Buren et al. 2011).

\section{Statement of the Problem}

Contemporary HRM textbooks (e.g., Mathis et al. 2014) make the case to business administration students that the HRM function acts as an employee advocate, serves as the voice of employees to executives and first line managers, and protects the organization's most valuable assets, the human assets. Unfortunately, it is increasing difficult to reconcile the HRM professional's endeavor to represent the interests of investors and management, all the while claiming to advocate for employee interests. This paper argues the case that, as the HRM function refocuses itself time and again on wider organization-centric (i.e. value-adding) foci, it inevitably does so to the detriment of traditional concerns about employee-relations, thus reducing employee advocacy to a benign option.

\section{Terminology and Progression of this Critical Commentary}

The terms labor, workers, and employees are used collectively and interchangeably, as is the case with the terms capital, investors, and management. Pathology, as referenced in this paper, is construed as both a deviation from propriety and normality and as a linguistic malfunction leading to accumulated social ills as per Merriam-Webster 2014.

As a critical commentary, we begin by defining the theoretical perspective from which we approach the phenomenon at the heart of this study. We then move to a discussion of environmental changes that likely germinated the situation facing HRM professionals today and then proceed to examine how attempts to control and dominate the language defining the nature of HRM within organizational contexts have wrought seemingly irreconcilable paradoxes. We progress to reflecting on how these complicated paradoxes contributed to a pathology that ultimately restricts HRM's motivation and ability to act as employee advocates. We conclude our commentary by considering how that pathology drives an employment relationship in which workers are severely disadvantaged because of a power imbalance. 


\section{Theoretical Perspective}

This critical commentary responds to Maclarean's (2011) challenge to question the taken-forgranted nature of work and representations of organizational reality. It reflects numerous admonitions (e.g., Alvesson and Deetz 1996; Grey and Willmott 2005; Adler et al. 2007) that the objective of any study of a managerial phenomenon should be to confront and disrupt existing knowledge and relationships in ways that open up alternative approaches to management that are more desirable and less destructive. By doing so, we hope to encourage reflective thinking in which the reader is motivated to consider the perspectives put forth in this paper and to make sense of them within the context of his/her own role as scholar or practitioner.

The particular lens employed in our commentary is Critical Management Studies (CMS). A core premise of CMS is that market competition forces firms to treat employees and environment as mere means toward the end of profit maximization, but the root of the problem is not the profit motive itself but the absence of counter balancing forces (Adler et al. 2007). As such, CMS thought reflects a deep skepticism regarding the moral defensibility and the social sustainability of the prevailing forms of management and organizations (Gray and Willmott 2005; Adler, et al. 2007) and vigorously questions the validity of contemporary management knowledge and practices (Dainty and Loosemore 2013). To the point, CMS holds that the supposed natural workplace relationships demand a critical examination because that which is assumed as given and natural too frequently masks underlying structural power and ideological differences between managers and employees, capital and labor, and men and women (Visser 2010).

\section{Prelude to Incongruities}

\section{A Changing Labor Landscape}

Traditionally, "labor" has been conceptualized as the body, or class, of individuals (e.g., employees and workers) engaged in a productive activity for the sake of individual economic gain. This concept of labor is distinct from the traditional concept of "capital that has been traditionally considered material wealth (e.g., buildings, land, cash and securities, and patents), controlled by individuals or enterprises (e.g., owners, managers, investors, and boards) and made available and capable for uses in the production of further wealth by these entities. As an economic system, capitalism has been labeled as one in which the means of production are owned and controlled by a small majority, and the mass of individuals, cut off from control of productive resources, is forced to sell their labor to simply survive (Bowles and Gintis 1975).

For more than five decades, a consensus existed wherein professionals tasked with management of human resources acted as advocates for the concerns of labor, and as a matter of propriety and normality assumed the role of protector of worker or employee welfare (Wright 2008; Van Buren et al. 2011). There is little doubt that those tasked with personnel and human resource issues often had to walk a fine line between the needs of employees (i.e., promoting worker welfare) and the needs of the organization (i.e., selecting, deploying, and making use of people to maximize productivity and cost efficiency). Yet, the employee advocacy role was generally considered normal and proper as it complemented production-oriented workflow systems composed of demonstrable tasks (Brown et al. 2009). From the late 1940s to the early 1970s nearly one of every three non-agricultural workers in the U.S. was represented by a 
legitimate bargaining unit (Casey 2013), and in those situations where the human resource system failed to properly assume an advocacy role, unions stood ready to redress worker grievances. Even employers with a weak concern for worker welfare generally opposed unionism with such a vengeance as to enable the Employee Relations, Personnel Administration, or HRM functions to advocate for the construction of generous compensation, benefit plans, and utilization of employee attitude surveys to address employee welfare concerns in a desire to suppress the influence of unions (Lewin 2001; Godard 2014).

However, changes in the economic and political climate beginning in the early 1980 s acted to relieve employers of a great deal of pressure to consider worker concerns and interests (Guest 1987). For example, government at the state and federal level began providing unemployment insurance on an economy of scale not possible from unions. Further, union lobbying for higher wages, benefits, and better working conditions became increasingly restricted by market realities considerably dissimilar to the rapid growth in GDP in the 1950 s, 60s, and into the early 70 s that encouraged employers to consent to union demands. As such, business organizations came to operate at such lower profit margins that the available "rent" to be extracted dried up - limiting union bargaining power. As well, nonunion firms increasingly adopted rules and procedures that conformed to and often served as substitutes for union workplaces, thus removing the hallmarks of union representation (Lewin 2001; Godard 2014). Further, the introduction of large amounts of worker protection legislation over five decades made refuge from managerial abuse, once available only through union membership, largely irrelevant (Oliver 2000). Finally, employers increasingly, and purposely, contributed to union obsolescence through use of contingent workers (Michie and Sheehan 2005), job outsourcing (Oliver 2000), and job off-shoring (Friedman 2007). Coupled with an evolving commerce oriented toward production of services and ideas rather than industrial output and the increasing substitution of technology for labor (see Thompson 2014), the declining threat of unionization as an available counter to capricious employer behavior reduced the normality and propriety of organizational concern about the need for employee champions.

\section{Simultaneous Desire to Enhance Organizational Status}

During the decades in which the HRM function served as an employee advocate, it was often under criticism as not being part of the organization's business model (Ellig 1997). For instance, in a 2004 study, the most frequently cited barrier to career advancement for HR professionals was the HRM function not being held in high enough esteem at the executive level (SHRM Global Forum 2004). Widely reported reasons for such a lack of esteem include:

1) The HRM focuses on issues of employee advocacy at the exclusion of business needs (Brown et al. 2009),

2) HRM represents a cost center rather than an opportunity for revenue generation (Tracey and Nathan 2002),

3) Little reason exists to consider the HRM function as playing a strategic role because it most often reports to the CFO rather than the CEO (Hammonds 2005; Vosburgh 2007),

4) HRM activities appear to only act as a support activity and contribute nothing to consumer delight that justified a premium charge for a product or service (Hammonds 2005), and

5) The HRM function represents the last great organizational bureaucracy, existing only to propagate itself (Steward 1996). 
Such public charges leave small doubt that HRM professionals historically have suffered from a negative image, but in the 1980s, pressure to enhance the status of HRM significantly increased as corporate reengineering endeavors repeatedly questioned the need for HRM specialists in flatter organizational structures (Bolton 2011). A growing sense of urgency emerged among HRM professionals to have a "place at the table" where firm strategy is determined (Labedz and Lee 2011) and to become a strategic player rather than serving in roles as "people-people" or the "enforcers of organizational policy" (Beatty and Schneier 1997).

\section{Construction of New Realities and Troubling Incongruities}

\section{Redefining HRM as a Strategic Partner}

Ford (2001) argued that organizations are nothing more than linguistic constructions. Lefkowitz (2003) expanded on that concept by observing that rather than describing realities within an organization, language creates those very realities. That is, the workplace that employees experience is a product of language, and events are ultimately understood by the language that dominates dialogue about those events, not by employee experiences (Ford 2001). It matters not if a statement about what the HRM function is or does within an organizational setting is true or false (i.e., objective and falsifiable); more important is if the statements are accepted, saleable, or valid for a larger audience (Johnson and Duberley 2005, citing Berg 1989).

Embracing HRM ideas and concepts advanced in books such as Managing Human Assets (Beer et al. 1984), HR Champions (Ulrich 1997), and The HR Value Proposition (Ulrich and Brockbank 2005), thought leaders in the HRM profession purposely moved to change the language dominating discussion about the role of the HRM function. The new language shifted the focus from a concern for labor (i.e., managing people) to a concern about providing empirical links between people management practices and company performance (LengnickHall et al. 2009; Bolton 2011). This shift in language was laden with expressions such as "strategic," "value added," and "customer advantage" (Francis and Keegan 2006). This communication spoke of the desirability of the HRM function becoming a strategic partner at the executive level and being recognized for its ability to contribute to profitability, efficiency, and effectiveness by leveraging human assets through selection, allocation, deployment, development, management, and retention (Morgan-Youssef and Stark 2014). The new language emphasized HRM's potential to influence work force behaviors that achieve valueadded operational and financial outcomes by creating cultures ensuring that the work force engages in "right" behaviors that produce the "right" operational outcomes (Beatty and Schneier 1997; Godard 2014).

Changing the language in the dialogue about HRM definitely created a new reality, one that was accepted, saleable, and valid for a large majority of individuals at the C-level of organizations, and it has resulted in human resource professionals having more power in employment matters than at any point in the past (Van Buren et al. 2011). Carlos Valdes, HR Director for Comcast Cable stated, “....there is no turning back. Today's HR strategic partner not only has gained a seat at the table with the major decision makers of an organization, but also assumes a prominent role as a chief advisor in the organizational structure of the a company" (Hispanic Executive 2013). Vanessa Vidal, President of ESQ Recruiting proclaimed, "Strategic HR departments understand their organization's business, how the 
money flows, and what drives growth and profitability. They also run their departments like a business by thinking about what would best serve the overall business, and by proactively contributing to the development and accomplishment of the organization-wide business plan and objectives" (Hispanic Executive 2013).

Emerging empirical evidence suggests that HRM professionals are embracing the language of strategic business partner with small forethought regarding the incongruities it generates. Research by Labedz and Lee (2011) on mental models held by HRM professionals concluded that situations in which labor relations experience creates viable employee-focused mental models are undergoing a sharp decrease; conversely, these are being replaced by mental models that focus on programs and policies remote from labor, placing a high priority on total rewards and emphasizing non-people issues. Research by Van Buren et al. (2011) concluded that while employee relations is considered a responsibility of the HRM function, employee relations is no longer seen as important to the ongoing role of HRM; in contrast, the role of the HRM function is highly focused on its strategic importance. A study by Brown et al. (2009) concluded that while contemporary HR managers may indeed undertake employee-centered roles, it is now accompanied by the expectation that such action is done to augment organization performance and that this attempt to blend both the role of strategic business partner with employee advocacy has recast the HRM function as "agents of capital." Research by Francis and Keegan (2006) suggests that the concept of "business partnering" (e.g., being seen as a strategic business partner) dominates dialogue about HR policy and practice but ignores serious concern about HRM's relationship with employees and involvement with issues of employee well-being.

The Incongruity The move from managing people to making direct contributions to a firm's competitive position has raised the visibility and influence of HR in the 21st century (Lengnick-Hall, et al. 2009), but the HRM function acting as employee advocate concerned with worker welfare is ultimately devolving into a matter of legal compliance rather than an ethical obligation (Brown, et al. 2009). Edwin Lawler, III, noted Director of the University of Southern California's Center for Effective Organizations argued that HRM professionals should abandon (at least for some indeterminate length of time) the employee-advocate role because keeping a focus on being an employee-advocate makes it difficult to be seen as a strategic business partner (Labbs 1998).

Whereas the employee management practices of the past were based on an understanding of the plurality of interests between labor and capital, the language about strategic HRM has so far been overwhelmingly focused on the priorities of owners and investors (Jackson et al. 2014). Lawler III and Mohrman (2003) argue that the traditional HRM focus on being an employee advocate does not permit being a strategic business partner. Although HRM professionals must be experts on what attracts people to the organization, what keeps them there, and what motivates them to be productive, being an employee advocate or champion should not be part of the equation (Reilly and Williams 2006). To the point, Lawler III (2005) argues that as a business partner HRM should be providing service by designing and implementing systems that resolve business problems and exert influence across the organization. Thus, the new prose drives HRM professionals to increasingly design and implement workplace selection systems focused on weeding out people who are different (e.g., not likely to become a team player or characterized as a poor fit within the organizational culture), training and development systems concentrated on indoctrination and soft skills development (e.g., training employees in the right way to think and act at the expense of technical and 
intellectual capabilities necessary to get things done), and performance measurement and pay systems fixated on auditing, controlling, and assigning accountabilities rather than fairness in the exchange (Godard 2014; Abbott 2015).

From the CMS perspective, due to an unequal power distribution, management dominates and controls the use and even the meaning of words in any dialogue about the HRM function, thus transforming and reshaping organizational reality to its own ends and outweighing any reality common to employees. Management's unrestricted power to drive a language about the strategic HRM function has resulted in employees being seen as individual resources to be configured and managed optimally (Bolton and Houlihan 2007). Such power acts to authorize HR-managers to prescribe a blueprint of employee attitudes, values, and behaviors promoted as necessary to realize the organization's grand vision of the future (Abbott 2015). With no competing narrative, the vernacular contributes to usurping the hands, hearts, and minds of labor and utilizing the emotional energies of employees in pursuit of the highly focused strategic goals of capital (Bolton 2011). As the language continues to drive a conceptual divorce of employees from their social context, workplace relations, and workplace commitments, the literature over the past three decades reveals an unmistakable increase in job dissatisfaction, work intensification, job insecurity, and decreases in feelings of economic and social equality (Bolton and Houlihan 2007; Bolton 2011), all suggesting a harbinger of ills yet to come.

\section{Redefining Labor as Capital}

In Progress and Poverty, Henry George (1911) argued that as factors of production "labor" is human exertion (both physical and mental), "capital" is the physical products of human labor, and that they are not convertible into each other. Thus, the interests of labor would appear distinct and mutually exclusive of the interests of capital. However, within the jargon dominating discourse about the HRM function, the conceptualization of labor and capital has become muddled, and the mutual exclusivity of each is increasingly disregarded.

If, as Ford's (2001) and Lefkowitz's (2003) argue, the workplace employees experience is the product of a language by which events ultimately are not understood by the their realities but by the dialogues about those events, then labor in the workplace has been redefined as a form of capital. The language that HRM scholars and professionals widely espouse speaks of elements of labor (i.e. the interests of employees and workers) as capital types (specifically, "human capital"). It postulates that knowledge, skills, abilities, personalities, attitudes, and motives of workers and employee are forms of internal and inimitable organizational resources that can be applied to achieve strategic competitive advantages (Dierickx and Cool 1989; Peffer 1994; Bush et al. 2001; Boudreau and Ramstad 2005). The new language confirms that employees and workers are a product of an emerging political ideology, a new economic order, and a more flexible form of capitalism (Bolton 2011). Thus, in the reality wrought by this new language, the HRM function is continually driven to construct strategies for leveraging labor toward pursuit of sustainable competitive advantages in the generation of even greater capital. It is unavoidable that justifying managerial actions based on transaction cost theory (which is in itself very skeptical of issues regarding human morality) influences the way in managers approach employment-related issues of performance (Ghoshal and Moran 1996). 
The Incongruity From a CMS perspective, it is unavoidable that such language must affect how HRM professionals perceive themselves and their tasks, how they make sense of their work and perform their managerial duties, and has far reaching implications for the employeremployee relationship (Wickert and Schaefer 2015). A well-understood concept in free market economics is that while actual labor productivity will normally fall short of the peak performance possible, the value of the average product of labor will generally exceed the value of the wage paid to the worker, thus aiding in the generation of profit. Reinterpreting an argument made by Bowles and Gintis (1975), a CMS perspective advocates that profits from human capital are maximized by HRM strategies that exploit labor to the fullest (i.e., getting as much labor as possible out of each individual employee). Further, the potential for profit is enhanced by additional strategies that hold down the wages paid for that labor.

Thus, it is not difficult to make a case that the evolving language about labor as capital and the increasing emphasis on HRM strategies to fully leverage that capital generates a reality that motivates management to implement mechanisms capable of extracting from workers a level of labor at a wage not reflective of employee contribution. A CMS assessment would question if the prevailing language about human capital produces a systemic corrosion of moral responsibility where any concern for employees requires justification in terms of its contribution to profitable growth (Alder et al. 2007). If the answer to that question is affirmative, then the HRM function is confronted with a fundamental decision. That is, either HRM advocates that workers and employees are to be equivalently rewarded for the value of their newly recognized capital toward increases in organizational performance or HRM designs and implements ever increasing strategies to further lever that capital and thereby solidify HRM's position as a strategic business partner.

\section{The Emergence of a Strange Pathology}

If we accept the common usage of the term "pathology" (i.e., the collective features used to describe behaviors characteristic of an abnormality) and if we accept that a pathology can encompass a linguistic abnormality or malfunction that alters the meaning of a shared reality (e.g., consider a report of a city's inability to cope with the pathology of a burgeoning underclass), then it is reasonable to suggest that by striving to position itself as "strategic in nature," the HRM profession will present signs of a strange and perplexing oddity. For instance, the language about the HRM function being both a strategic business partner while remaining an employee advocate certainly suggests an aberration of a previously shared reality. The abnormality is observable as HRM increasingly relegates the role of employeechampion to a lesser degree of concern than in past decades (Labedz and Lee 2011), accepts the use of employees as economic ends in the interests of capital (Wilcox and Lowry 2000), and acts as an agent for the interests of capital rather than an agent for the concerns of labor (Wright 2008).

This strange pathology is further recognizable through a malfunction in language about the strategic nature of HRM that legitimizes practices once considered radical such as downsizing at the first sign of economic stress, increasing use of contingent workforces to improve bottom line results (Cavanaugh and Noe 1999), and driving labor out of the marketplace by substituting technology (Sartain 2014). A further malfunction of the language about the strategic nature of HRM is observable in the 
assumption that employee well-being and organizational goals can always be aligned (Purcell et al. 2003). One has to look no further than an example provided by Marissa Mayer, the CEO of Yahoo, who upon taking control of the firm made news by discontinuing the practice of telecommuting. Mayer's justification for the decision was that the move was necessary to increase the potential for exchange of creative ideas that might advance the competitive position of the firm. However, it is not unreasonable to argue that Mayer (and the HRM function as a strategic business partner at Yahoo) abandoned all the literature has revealed about working parents and their desire for work-life balance in order to pursue a rise in Yahoo's stock value (Surowiecki 2013). Meg Whitman, CEO of Hewlett-Packard, quickly followed Yahoo's HRM practice by announcing that she wanted all HP employees to work at the office and discontinue telecommuting (Marketplace 2013). In summary, the language about the strategic value of HRM malfunctions across numerous fronts in that it positions the HRM function to exercise increased strategic influence while gambling with employee well-being (Francis and Keegan 2006).

Without doubt, claims have been advanced that High Performance Work Practices reflective of human capital strategies, especially when integrated into coherent High Performance Work Systems rather than adopted as isolated individual practices, have demonstrated a significant positive influence on organizational performance (Huselid 1995; Combs et al. 2006; Aryee et al. 2012). On the other hand, perhaps such claims stand as evidence of the operation of the strange pathology at the heart of this paper. To pursue this further, it is reasonable to consider how language has malfunctioned since inception of the discussion about the existence and role of human capital. In his presidential address to the American Economic association, Theodore Schultz's (1961) opening statement was, "Although it is obvious that people acquire useful skills and knowledge, it is not obvious that these skills and knowledge are a form of capital, (or) that this capital is in substantial part a product of deliberate investment" (p. 1). As such, he issued a caution against forgetting the humanity of labor. To the point, language through which labor is changed into capital reveals an abnormality that is pathological because it values employees for their resourcefulness rather than their humanity (as cautioned by Schultz), and the increased reliance on human capital metrics represents a distortion of the employer-employee relationship (Van Buren et al. 2011).

Both Becker (1964) and Schultz (1961) were careful to emphasize that humans are not "capital", but rather are "capitalists" through acquiring knowledge, skills and other forms of human investments that have economic value. Schultz (1961, p. 2) emphasized "free men (as) ... the end to be served by economic endeavor" and "wealth exist(ing) only for the sake of the people." The pathology that demands defining labor as another form of capital compels a malfunction of language because it implies that like other forms of material wealth this capital is controlled by owners, managers, investors, boards, etc. and exists solely for use in the production of further wealth by these entities. Succinctly, the linguistic shift toward discussion of labor as human capital malfunctions because it fails to recognize that employees represent a distinctive "stakeholder group" with concerns and interests not necessarily germane to those of a strategic business partner (Godard 2014). This shift in language malfunctions because it acts to degrade humans, reducing them to a form of property that can be owned and manipulated by other entities, not necessarily incomparable to language used in discussion of slavery. 


\section{A Shifting of the Power-Dependency Ratio and Resulting Social Ills}

A wide spread pathological condition usually points toward an eventual accumulation of ills, and in the context of this paper one such ill is socially observed in the increasing shift of the power-dependency ratio toward the interests of capital. While scholars and academicians may find it difficult to arrive at a definition, power is readily recognizable by the ability of those who possess it to bring about outcomes they desire (Salancik and Pfeffer 1983). To possess power is to possess the ability to influence others (Wartenberg 1990). A common thread running through most discussions of power and influence is the existence of some dependence of one actor on another actor because of a unique control over needed resources (Manz and Gioia 1983), and from this dependence springs the power to influence the choices and behaviors of the dependent actor.

From the realm of popular culture to the realm of politics there is wide spread suspicion regarding ideologies justifying various management techniques, and this suspicion gives rise to a concern that they serve the needs of the industrial systems and "power elites" rather than improving the general quality of experienced life or offering opportunities for meaning and community (Mclaran 2011). CMS scholars share a common principle that the use of power in any oppressive manner to benefit some groups to the determent of others is both unjust and socially destructive (Murphy et al. 2013) and argue that we must disclose and make public the concealed power relations that structure and reaffirm the existing social, political, and economic environment (Mclaran 2011).

Power in the employment relationship is generally unbalanced where, with the exception of an economy at full employment, the employer holds sway over the workers and employees. Certainly, some individual employees perceived by management to possess rare and valuable forms of knowledge, skills, abilities, and experience indeed may be able to exercise a counter balance of power and influence in the employment relationship. However, the greater the degree that labor is perceived to be a commodity, the less power there is to change the employment relationship. As such, for all the language about employees representing human capital, most employees receive contracts of adhesion, structured by their employers, which can be taken or rejected, but not changed. This lack of power makes it extremely difficult for employees to ensure that they are treated fairly (Van Buren et al. 2011).

The current language defining the HRM function as a strategic business partner advocates the necessity for this power imbalance and argues that any conflict arising from the power imbalance is not a social concern but rather an internal matter stemming from poor management within the organization. With the HRM function driving an organizational ideology that masquerades as a desired culture, management acts to dissuade employees for engaging in dissenting behaviors or even thinking in dissenting terms by making available at the appropriate time all of the rewards of organizational life, real or imagined, to those who display the correct behaviors, attitudes and values (Abbott 2015). The new organizational reality does not require HRM to advance employee interests and goals directly, but rather requires championing organizational, procedural, and management improvements that eventually align the goals and objectives of employers and employees, thus enabling efficient and effective organizational operations (Lewin 2001). Any suggestion that employees desire an independent voice in decisions that affect their interests is interpreted as a failure attributable to poor management of a firm's human resources (Kochan 2004). CMS scholars counter that there 
must be a desire to transform existing power relations in organizations with a view toward encouraging less oppressive practices that do not harm social and environmental welfare (Fleming and Banerjee 2016).

\section{Conclusion}

Is it possible for the HRM function to act as a strategic business partner and at the same time advance the interests of workers and employees? Human Resource managers and professionals appear to believe sincerely that enlightened management will align the interests of all parties to the employment relationship and thus make redundant separate and independent consideration of worker and employee interests and goals (Kaufman 2001). To the point, HRM thinking suggests that the bulk of organizations (over the long run) will come to promote the interests of employees and work toward accomplishment of fundamental human values. However, Kaufman (2001) pointed out that this proposition relies on two assumptions: 1) The HRM function will be able to convince managers to recognize that doing so leads to greater organizational efficiency and 2) Managers are ethical people and will subscribe to ethical principles. The existing power imbalance likely makes false any such hopes (Van Buren et al. 2011). One might consider that Warren Buffet, the third richest capitalist in the world, openly admitted that past gains in productivity have largely benefited capital. Yet, he boldly proclaimed in his annual letter to shareholders in his firm that as the market system interact to produce even greater efficiencies demanded by investors, many workers will be rendered unnecessary, their skill and talents obsolete (Hubbard 2016). Organizations are more effective at achieving their goals if they make it difficult for most employees to achieve theirs, and this is particularly so when employees lack the power to affect the terms of exchange with their employers. Thus, competitive market forces and failures will always provide employers with both the pressure and the ability to deal with labor in ways that are inimical to employee values and societal interests (Kaufman 2001)

Any intention of the HRM function to act as a champion of the employees will, of necessity, give way to the demand of being seen as a strategic business partner. Perhaps nowhere will this be more evident within the coming decades than in industries where digital solutions such as new generations of low-cost and easy-to-program robots and purpose-built automated machines will significantly devalue and/or displace millions of humans in the workforce (Sartain 2014). Workers employed in the shrinking number of viable jobs will be even further disadvantaged, and with the HRM function rushing to claim the mantel of strategic business partner while devaluing the role of employee advocate and champion, to whom can employees turn to ensure that labor benefits equally from capital's increasing power?

\section{References}

Abbott, K. (2015). The totalitarian dynamic behind HRM's democratic façade. Asian Pacific Journal of Human Resources, 53(2), 204-220.

Adler, P. S., Forbes, L. C., \& Willmott, H. (2007). Critical management studies. The Academy of Management Annals, 1(1), 119-179.

Alvesson, M., \& Deetz, S. (1996). Critical theory and postmodernism approaches to organizational study. In S. R. Clegg, C. Hardy, \& W. R. Nord (Eds.), Handbook of organizational studies (pp. 191-217). London: Sage. 
Argyris, C. (1957). Personality and the organization: The conflict between the system and the individual. New York: Harper.

Aryee, S., Walumbwa, F. O., Seidu, E. Y. M., \& Otaye, L. E. (2012). Impact of high-performance work systems on individual- and branch-level performance: test of a multilevel model of intermediate linkages. Journal of Applied Psychology, 97, 287-300.

Beatty, R. W., \& Schneier, C. E. (1997). New HR roles to impact organizational performance: from "Partners" to "Players.". Human Resource Management, 36(1), 29-37.

Becker, G. S. (1964). Human capital. New York: Columbia University.

Beer, M., Spector, B., Lawrence, P. R., Mills, D. Q., \& Walton, R. E. (1984). Managing human assets. New York: Free Press.

Berg, P. O. (1989). Postmodern management? From fact to fiction in theory and practice. Scandinavian Journal of Management, 5, 201-217.

Bolton, S. C. (2011). Critical human resource management. In M. Tadajewski (Ed.), SAGE key concept series: Key Concepts in critical Management Studies. London: Sage UK.

Bolton, S., \& Houlihan, M. (2007). In Bolton \& M. Houlihan (Eds.), Searching for the H in HRM (pp. 1-18). London: Palgrave.

Boudreau, J. W., \& Ramstad, P. M. (2005). Talentship: talent segmentation and sustainability: a new HR decision science paradigm for a new strategy definition. Human Resource Magazine, 44(2), 129-136.

Bowels, S., \& Gintis, H. (1975). The problem with human capital theory-A Marxian Critique. The American Economic Review, 65(2), 74-82.

Brown, M., Metz, I., Cregan, C., \& Kulik, C. T. (2009). Irreconcilable differences? Strategic human resource management and employee well-being. Asian Pacific Journal of Human Resources, 47(3), 270-294.

Bush, C. G., Greene, P. G., \& Hart, M. M. (2001). From the initial idea to unique advantage: the entrepreneurial challenge of constructing a resource base. Academy of Management Perspectives, 15(1), 64-78.

Casey, L. (2013). America's union suppression movement (ant its apologists), part one. Albert Shanker Institute. Retreived at http://www.shankerinstitute.org/blog/america's-union-suppression-movement-and-itsapologists-part-one. Accessed 25 Jul 2016.

Cavanaugh, M., \& Noe, R. (1999). Antecedents and consequences of relational components of the new psychological contract. Journal of Organizational Behavior, 20(3), 23-340.

Combs, J. G., Liu, Y., Hall, A., \& Ketchen, D. (2006). Do high performance work practices matter? A metaanalysis of their effects on organizational performance. Personnel Psychology, 59, 501-528.

Dainty, A., \& Loosemore, M. (2013). Human resource management in construction: Critical perspectives (2nd ed.). New York: Routledge.

Dierickx, I., \& Cool, K. (1989). Asset stock accumulation and sustainability of a competitive advantage. Management Science, 35, 1054-1513.

Ellig, B. R. (1997). Is the human resource function neglecting the employees? Human Resource Management, 36(1), 91-95.

Fleming, P., \& Banerjee, S. B. (2016). When performativity fails: implications for critical management studies. Human Relations, 69(2), 257-276.

Ford, J. (2001). Call for papers. Academy of Management Review special topics forum. Language and organizations. Academy of Management Review, 26, 328-330.

Francis, H., \& Keegan, A. (2006). The changing face of HRM: in search of balance. Human Resource Management Journal, 16(3), 231-249.

Friedman, B. A. (2007). Globalization implications for human resource management roles. Employee Responsibility Rights Journal, 19, 157-171.

George, H. (1911). Progress and Poverty: An inquiry into the cause of industrial depression and of increase of want with increase of wealth. Garden City: Doubleday, Page \& Company.

Ghoshal, S., \& Moran, P. (1996). Bad for practice: a critique of the transaction theory. Academy of Management Review, 21(1), 13-37.

Godard, J. (2014). The psychologisation of employment relations? Human Resource Management Journal, 24(1), 1-18.

Grey, C., \& Willmott, H. (2005). Critical management studies: A reader. Oxford: Oxford University Press.

Guest, D. E. (1987). Human resources management and industrial relations. Journal of Management Studies, 24(5), 503-521.

Hammonds, K. (2005). Why we hate HR. Fast Company, 97. Retrieved at http://www.fastcompany.com/53319 /why-we-hate-hr. Accessed 23 Mar 2013.

Hispanic Executive (2013). Retrieved at http://hispanicexecutive.com/2013/in-what-ways-does-hr-now-functionas-a-strategic-business-partner/. Accessed 5 Apr 2015. 
Hubbard, R. (2016). Rooting out inefficiency is painful, oracle says. Omaha World-Herald. Retrieved at http://www.omaha.com/edition/sunrise/.articles/rooting-out-inefficiency-is-painful-oraclesays/article 70980789-fbe3-5503-a5b1-b0f21737738d.html. Accessed 16 Mar 2016.

Huselid, M. A. (1995). The impact of human resource management practices on turnover, productivity, and corporate financial performance. Academy of Management Journal, 38, 635-672.

Jackson, S. E., Schuler, R. S., \& Jiang, K. (2014). An aspirational framework for strategic human resource management. The Academy of Management Annals, 8(1), 1-56.

Johnson, P., \& Duberley, J. (2005). Understanding management research. London: Sage.

Kaufman, B. E. (2001). Human resources and industrial relations commonalities and differences. Human Resource Management Review, 11, 339-374.

Kaufman, B. E. (2008). Managing the human factor: The early years of human resource management in American industry (1st ed.). Ithaca: ILR Press/Cornell University Press.

Kaufman, B. E., \& Aldao-Zapiola, C. (2014). The development of human resource management across nations: Unity and diversity. Cheltenham, England. Northampton: Edward Elgar.

Kochan, T. A. (2004). Promise and peril in implementing pay-for-performance systems: comment by Thomas Kochan. Human Resource Management, 43(1), 35-37.

Laabs, J. (1998). Why HR can't win today. Workforce, 77(5), 62-74.

Labedz, C. S., \& Lee, J. (2011). The mental models of HR professionals as strategic partners. Journal of Management \& Organization, 17(1), 57-76.

Lawler, E., III. (2005). From human resource management to organizational effectiveness. Human Resource Management, 44(2), 165-169.

Lawler, E. III, \& Mohrman, S. A. (2003). HR as a strategic partner: What does it take to make it happen? Center for Effective Organizations, Publication G 03-2 (430).

Lefkowitz, J. (2003). Ethics and values in industrial-organizational psychology. Mahwah: Lawrence Erlbaum Associates.

Lengnick-Hall, M. L., Lengnick-Hall, C. A., Andrade, L. S., \& Drake, B. (2009). Strategic human resource management: the evolution of the field. Human Resource Management Review, 19, 64-85.

Lewin, D. (2001). IR and HR perspectives on workplace conflict: what can each learn from the other? Human Resource Management Review, 11, 453-485.

Maclaran, P. (2011). Introduction: What is critical management studies? In M. Tadajewski (Ed.), SAGE key concepts series, Key concepts in critical management studies. Sage UK: London.

Mantz, C. C., \& Gioia, D. A. (1983). The interrelationship of power and control. Human Relations, 36, 439-476.

Marketplace (2013). No more working at home for Hewlett-Packard employees. Retrieved at http://www. marketplace.org/topics/business/no-more-working-home-hewlett-packard-employees. Accessed 13 Nov 2013.

Mathis, R., Jackson, J., \& Valentine, S. (2014). Human resource management (14th ed.). Independence: CengageBrain Publishers.

Mayo, E. (1933). The human problems of an industrial civilization. New York: Macmillian.

McGregor, D. (1960). The human side of enterprise. New York: McGraw-Hill.

Merriam-Webster (2014). Retrieved at http://www.merriamwebster.com/dictionary/pathology. Access 29 Oct 2015.

Michie, J., \& Sheehan, M. (2005). Business strategy, human resources, labour market flexibility, and competitive advantage. International Journal of Human Resource Management, 16(3), 445-464.

Morgan-Youssef, C., \& Stark, E. (2014). Strategic human resource management: Concepts, controversies, and evidenced-based applications. San Diego: Bridgepoint Education.

Murphy, J., Malin, V., \& Siltaoja. (2013). Beyond critique: Towards transformative practice in critical management studies. Editor's introduction. In Murphy, Malin, \& Siltaoja (Eds.) Dialogues in Critical Management Studies, 2, xiii-xxxi.

Oliver, B. (2000). The future of unions. Retrieved http://economics.mit.edu/files/655. Access 15 Jun 2011.

Pfeffer, J. (1994). Competitive advantage through people: Unleashing the power of the workforce. Boston: Harvard Business School Press.

Purcell, J., Kinnie, N., Hutchinson, S., Rayton, B., \& Swart, J. (2003). Understanding the people and performance link: Unlocking the black box. Research Report. London: CIPD.

Reilly, P., \& Williams, T. (2006). Strategic HR: Building the capacity to deliver. London: Gower.

Salancik, G. R., \& Pfeffer, J. (1983). Who gets power-and how they hold on to it: A strategic-contingency model of power. In Straw \& M. Barry (Eds.), Psychological foundations of organizational behavior. Dallas: Scott, Foresman and Company.

Sartain, J. D. (2014). Smart machines could cost tech industry millions of IT jobs. CIO. Retrieved at http://www. cio.com/article/745220/Smart_Machines_Could_Cost_Tech_Industry_Millions_of_IT_Jobs. Accessed 3 Mar 2015. 
Schultz, T. W. (1961). Investment in human capital. The American Economic Review, 1, 1-17.

SHRM Global Forum (2004). The maturing profession of human resources management. SHRM Research. Retrieved at https://www.shrm.org/Research/SurveyFindings/Documents/The\%20Maturing\%20 Profession\%20of\%20HR\%20-\%20Worldwide\%20and\%20Regional\%20View\%20Survey\%20Report.pdf. Accessed 15 Aug 2013.

Sims, R. R., \& Sauser, W. I. (2014). Contemporary human resource management issues challenges and opportunities: Legal and regulatory issues in human resources management. Information Age Publishing.

Steward, T.A. (1996). Taking on the last bureaucracy: People need people, but do they need personnel? It's time for HR departments to put up or shut up. Retrieved at http://money.cnn.com/magazines/fortune/fortune archive/1996/01/15/207172/index.htm. Accessed 23 May 2010.

Surowiecki, J. (2013). Face time. The New Yorker. Retrieved at http://www.newyorker.com/talk/financial/2013 /03/18/130318ta_talk_surowiecki. Accessed 1 Apr 2014.

Thompson, D. (2014). The fastest-growing jobs of this decade (and the robots that will steal them). The Atlantic. Retrieved at http://www.theatlantic.com/business/archive/2014/01/the-fastest-growing-jobs-of-this-decadeand-the-robots-that-will-steal-them/283411/. Accessed 5 May 2015.

Tracey, J. B., \& Nathan, A. E. (2002). The strategic and operational roles of human resources. Cornell Hotel and Restaurant Administration Quarterly, 43(4), 17-26.

Ulrich, D. (1997). Human resource champions: The next agenda for adding value and delivering results. Cambridge: Harvard Business Press.

Ulrich, D., \& Brockbank, W. (2005). The HR value proposition. Boston: Harvard University Press.

Van Buren, H. J., III, Greenwood, M., \& Sheehan, C. (2011). Strategic human resource management and the decline of employee focus. Human Resource Management Review, 21, 209-219.

Visser, M. (2010). Critical management studies and "mainstream" organizational science: a proposal for rapprochement. International Journal of Organizational Analysis, 18(4), 466-478.

Vosburgh, R. M. (2007). The evolution of HR: developing HR as internal consulting organization. Human Resource Planning, 30(3), 11-23.

Vroom, V. (1964). Work and motivation. New York: Wiley.

Wartenberg, T. E. (1990). The forms of power: From domination to transformation. Philadelphia: Temple University Press.

Wickert, C., \& Schaefer, S. M. (2015). Towards a progressive understanding of performativity in critical management studies. Human Relations, 68(1), 107-130.

Wilcox, T., \& Lowry, D. (2000). Beyond resourcefulness: casual workers and the human-centered organization. Business and Professional Ethics Journal, 19(3 \& 4), 29-53.

Wright, C. (2008). Reinventing human resource management: business partners, internal consultants and the limits to professionalization. Human Relations, 61(8), 1063-86. 